\title{
A NOTE ON SOME HAEMATOLOGICAL AND SERUM CHEMICAL VALUES FOR CAPTIVE DORCAS GAZELLE (GAZELLA DORCAS) IN SUDAN
}

\author{
H. $\operatorname{AGAB}^{1 *}$; S.M. ELBASHIR ${ }^{2}$ and A.E. MOHAMED ${ }^{3}$ \\ 1- Sudan University of Science and Technology, P O Box 204, Khartoum North, SUDAN. hamidagab1@hotmail.com \\ 2- Animal Health Research Corporation, P O Box 8067, Khartoum, Al-Amarat, Sudan. \\ 3- Wildlife Research Centre, P O Box 16, ElMourada, Omdurman, Sudan. \\ *Corresponding author. \\ Email: hamidagab1@,hotmail.com
}

\section{ABSTRACT}

Received at: 7/9/2013

Some hematological and biochemical parameters were determined in blood Accepted: 7/10/2013 specimens collected from clinically healthy Dorcas gazelles (Gazella dorcas) bred in captivity in large enclosed areas in Khartoum State, Sudan. The average levels for the hematological and biochemical parameters studied were as follows; the total white blood cells (TWBC) count was $10.09 \pm 1.50 \times 103 / \mathrm{mm}^{3}$, the red blood cells (TRBC) count was $11.7 \pm 1.78 \times 106 / \mathrm{mm}^{3}$, the total haemoglobin $(\mathrm{Hb})$ concentration was $18.85 \pm 1.10 \mathrm{~g} / \mathrm{dl}$, the packed cell volume $(\mathrm{PCV})$ was $51.64 \pm 3.2 \%$, the mean cell volume $(\mathrm{MCV})$ was $5.1 \pm 0.86 \mathrm{fl})$, the mean cell haemoglobin $(\mathrm{MCH})$ was $16.5 \pm$ $0.23 \mathrm{pg}$, the mean cell haemoglobin concentration (MCHC) was $36.68 \pm 0.77 \mathrm{~g} / \mathrm{dl}$, the glucose level was $66.6 \pm 20.0 \mathrm{mg} / \mathrm{dl}$, the alanine aminotransferase (ALT) enzyme activity level was $50 \pm 12.0 \mathrm{IU} / 1$ and the aspartate aminotransferase (AST) enzyme activity level was $372.4 \pm 75.0 \mathrm{IU} / \mathrm{l}$, the calcium level was $8.88 \pm 0.26 \mathrm{mg} / \mathrm{dl}$, the inorganic phosphorus level was $6.9 \pm 0.50 \mathrm{mg} / \mathrm{dl}$, the sodium level was $154 \pm$ $5.1 \mathrm{mmol} / 1$, the potassium level was $4.98 \pm 0.37 \mathrm{mmol} / 1$, and the chloride level was $112.8 \pm 2.70 \mathrm{mmol} / \mathrm{l}$. These results were compared and discussed with the results of similar studies conducted on Gazella dorcas and other Gazella species elsewhere.

Key Words: Hematology, biochemical parameters, Dorcas gazelle, Sudan.

\section{INTRODUCTION}

In Sudan, gazelles (Gazella species) are found inhabiting the desert and semi-arid regions due to the availability of some few water resources and fresh succulent saline fodders (Thompson and Ghobrial, 1965). Gazelles are known as well adapted desert ruminants that can survive and produce under extreme harsh conditions. They can go their entire life without drinking as they can get all of the moisture they need from the plants in their diet. These gazelles feed on leaves, flowers and pods of many species of Acacia trees as well as the leaves, twigs and fruits of various bushes.

There are few published articles on the normal clinico-chemical and haematological profile of captive Dorcas gazelle (Gazella dorcas) in Sudan and elsewhere (Thompson and Ghobrial, 1965; Ghobrial, 1967; Ghobrial, 1970; Ghobrial, 1974; Bush et al., 1981; Mohamed et al., 1988; Faragalla et al., 2005; Sayied et al., 2011). Publications on the serum chemistry and haematology of other gazelle species include captive mountain gazelle (Gazella gazelle) (Reitherk and Detaima, 1994), captive grant gazelle
(Gazella granti) (Seal and Schobert, 1976), captive Gazella mhorr and Gazella cuvieri (Abaigar, 1993), Gazella thomsoni and Gazella dama (Drevemo et al., 1974) are well established.

In a study of the effect of seasonal variations on some serum, plasma and whole blood constituents in the Dorcas gazelle, Ghobrial (1967) found high values of urea, sodium and potassium during summer and low values during winter. The value of blood urea was, however, higher in winter. The conclusion that electrolytes level in the serum of captive Dorcas gazelle increases during summer was further confirmed by Reitherk and Detaima, (1994) but they recorded no influence of seasonality on packed cell volume and haemoglobin concentration. Mohamed et al. (1988) studied the effect of dehydration followed by sub-sequent rehydration on some parameters of Dorcas gazelle and concluded that dehydration resulted in reduced feed intake and decreased body weight, faecal water content, urine volume and glucose concentration. These effects were noticed to be reversed by rehydration. The latter authors also noted that dehydration resulted into increase of urea, albumin and serum electrolytes concentration in the studied Dorcas gazelles. 
In their analysis of the blood of Dorcas gazelles for haematological and serum chemical values, Bush et al. (1981) recorded some variations associated with difference in age where they found a significant difference between the neonates, juvenile and adult groups in total protein, calcium, phosphorus, cholesterol, total bilirubin levels, ALP and LDH activity levels. They also found that males had significantly higher values of glucose. The effect of sex on the serum biochemical parameters was also studied by Marler (1975) who found no significant differences in the studied parameters unlike the effect of age on these studied parameters. It was reported that quick capture of zoo animals, including gazelles, had an influence on some of the haematological parameters to be investigated in these animals as it was noted that this practice had increased the circulating erythrocytes due to splenic concentration and to the significant decrease in erythrocyte size and haemoglobin (Hb) content (Hawkey et al., 1980).

Normal physiological data from wild species are often difficult to obtain, because the number of animals available for study is generally limited, and frequent and systematic sampling can disrupt the management and well-being of these animals. Haematological and biochemical values are important for assessing the health and nutrition of the animals. Therefore, it is essential for the evaluation of clinical tests in veterinary laboratories that a base reference of normal values of clinically healthy animals is available.

The present note was aimed at further provision of basic haematological and serum chemical values for captive Gazella dorcas as the interest in game ranching in Sudan, particularly gazelles breeding, for export is witnessing increasing interest.

\section{MATERIALS and METHODS}

Animals and feed: Dorcas gazelles involved in this investigation were kept in captivity in three different gazelle farms, namely; 6-April Zoo, Al-Qurashi Zoo and Azeez Al-jimaiaabi Farm, which all located in Khartoum area of the three-towned national capital of Sudan. All animals were apparently healthy with no clinical signs of any disease. The ages of the gazelles ranged from 3 to 4 years. The animals were fed a roughage composed of either Medicago sativa (alfaalfa) or Sorghum bicolar (Abu 70) hay ad libitum and about half a kilogram of sorghum grains for each gazelle every day. Drinking water was available all time. Animals were either captured by hand or by using a net.

Blood collection and samples analysis: Whole blood was drawn from the jugular vein into heparinized vacutainer tubes using disposable syringes. Immediately after collection, tubes containing whole blood were placed in thermo-flasks containing ice, transferred to the laboratory and analyzed on the same day. Blood for serum analysis, on the other hand, was collected into plain vacutainer tubes, allowed to clot during transportation to the laboratory where tubes were centrifuged at 3000 round per minute (r.p.m.) and then the separated serum was stored at $-20{ }^{\circ} \mathrm{C}$ till analysis. Animals of both sexes were sampled including 12 animals of each sex, among these 13 animals were sampled during the summer season and 11 animals during the winter season.

\section{Laboratory analysis:}

The whole anti-coagulated blood was used immediately, at Kuku Veterinary Diagnostic Unit, Khartoum North, for the determination of total erythrocyte count, packed cell volume (PCV), hemoglobin $(\mathrm{Hb})$ concentration and total leukocyte count according to the method of Dacie and Lewis (1992). A colorimetric method was adopted for the determination of serum concentration of total protein, albumin, urea, uric acid, creatinine, billirubin, calcium $(\mathrm{Ca})$, inorganic phosphorus $(\mathrm{P})$, magnesium $(\mathrm{Mg})$, copper $(\mathrm{Cu})$, chloride $(\mathrm{Cl})$ and iron $(\mathrm{Fe})$ levels using commercial kits (Linear Chemicals Ltd. Spain). In a Uincum model 6265 UV/VIS spectrophotometer, each parameter was measured against specific wave length. Transaminases (ALT and AST) enzyme activities were determined according to Reitman and Frankel (1957). Serum sodium (Na) and potassium (K) were measured by a flame photometer (Corning 400, England). Blood glucose levels were estimated according to the method of Varley (1986).

Statistical analysis: Data obtained from the serum chemistry and whole blood investigation were analyzed using STATISTICA statistical analysis package. Analysis of variance (one-way ANOVA) was used to perform and tabulate serum chemistry and haematology values with sex and season variation according to Gomez and Gomez (1983).

\section{RESULTS}

The means and ranges of some serum biochemical parameters concentration levels of Gazella dorcas during winter and summer are given in Table 1. The figures for the two seasons did not show significant differences, except for urea where the values were very high during winter.

The values of different biochemical parameters in male and female Dorcas gazelles investigated are presented in Table 2 where no significant differences between male and female gazelles were observed.

The haematological values of the male and female Dorcas gazelles studied are shown in Table 3. Again, no significant differences could be observed between the two sexes of the gazelles studied. 
$\underline{\text { Assiut Vet. Med. J. Vol. } 59 \text { No. } 139 \text { October } 2013}$

Table 1: Means \pm SD of some serum biochemical values of Gazella dorcas during winter and summer.

\begin{tabular}{|c|c|c|c|c|c|c|c|c|c|c|c|c|c|c|}
\hline Parameter & $\begin{array}{c}\mathrm{Na} \\
\mathrm{Mg} / \mathrm{dl}\end{array}$ & $\begin{array}{c}\mathrm{K} \\
\mathrm{Mg} / \mathrm{dl}\end{array}$ & $\begin{array}{c}\mathrm{Mg} \\
\mathrm{Mg} / \mathrm{dl}\end{array}$ & $\begin{array}{c}\text { IP } \\
\mathrm{Mg} / \mathrm{dl}\end{array}$ & $\begin{array}{c}\mathrm{Ca} \\
\mathrm{Mg} / \mathrm{dl}\end{array}$ & $\begin{array}{c}\text { T.P } \\
\text { Mg/dl }\end{array}$ & $\begin{array}{l}\text { Albumin } \\
\text { Mg/dl }\end{array}$ & $\begin{array}{c}\text { Globulins } \\
\text { Mg/dl }\end{array}$ & $\begin{array}{l}\text { AST } \\
\mu \mathbf{l} / \mathbf{m l}\end{array}$ & $\begin{array}{l}\text { ALT } \\
\mu l / m l\end{array}$ & $\begin{array}{l}\text { Creatinine } \\
\qquad \mathrm{Mg} / \mathrm{dl}\end{array}$ & $\begin{array}{c}\text { Uric Acid } \\
\text { mg/dl }\end{array}$ & $\begin{array}{l}\text { Urea } \\
\mathrm{Mg} / \mathrm{dl}\end{array}$ & $\begin{array}{c}\text { Bilirubin } \\
\text { Mg/dl }\end{array}$ \\
\hline \multirow[t]{2}{*}{ Summer } & $114.9 \pm$ & $2.02 \pm$ & \multirow{2}{*}{$\begin{array}{l}1.1 \pm \\
0.61\end{array}$} & \multirow{2}{*}{$\begin{array}{l}5.1 \pm \\
1.70\end{array}$} & $12.3 \pm$ & $9.1 \pm$ & $3.4 \pm$ & $5.9 \pm$ & $93.8 \pm$ & $15.0 \pm$ & $394.1 \pm$ & $0.52 \pm$ & $42.0 \pm$ & $3.1 \pm$ \\
\hline & 5.11 & 0.35 & & & 5.16 & 3.89 & 1.24 & 2.83 & 55.72 & 8.55 & 79.59 & 0.28 & 14.89 & 2.48 \\
\hline \multirow[t]{2}{*}{ Winter } & $115.01 \pm$ & \multirow{2}{*}{$\begin{array}{l}2.3 \pm \\
0.45\end{array}$} & \multirow{2}{*}{$\begin{array}{c}0.90 \pm \\
0.54\end{array}$} & \multirow{2}{*}{$\begin{array}{l}6.3 \pm \\
2.13\end{array}$} & $13.0 \pm$ & $10.2 \pm$ & $2.4 \pm$ & $6.9 \pm$ & $87.1 \pm$ & $15.3 \pm$ & $293.5 \pm$ & $0.45 \pm$ & $109.3 \pm$ & $4.02 \pm$ \\
\hline & 6.62 & & & & 2.69 & 3.40 & 0.34 & 2.67 & 50.79 & 8.82 & 124.11 & 0.30 & 40.46 & 6.06 \\
\hline \multirow{2}{*}{$\begin{array}{c}\text { Overall } \\
\text { mean }\end{array}$} & $115.0 \pm$ & \multirow{2}{*}{$\begin{array}{l}2.1 \pm \\
0.40\end{array}$} & \multirow{2}{*}{$\begin{array}{l}1.0 \pm \\
0.57\end{array}$} & \multirow{2}{*}{$\begin{array}{l}6.7 \pm \\
1.97\end{array}$} & $12.6 \pm$ & $9.6 \pm$ & $2.9 \pm$ & $6.3 \pm$ & $90.7 \pm$ & $15.1 \pm$ & $345.0 \pm$ & $0.49 \pm$ & $72.8 \pm$ & $3.5 \pm$ \\
\hline & 5.72 & & & & 4.15 & 3.63 & 1.06 & 2.75 & 52.47 & 8.48 & 112.35 & 29 & 44.72 & 4.40 \\
\hline $\begin{array}{c}\text { Level of } \\
\text { Significance }\end{array}$ & N.S & N.S & N.S & N.S & N.S & N.S & N.S & N.S & N.S & N.S & N.S & N.S & $* *$ & N.S \\
\hline
\end{tabular}

N.S. $=$ Indicates non-significant difference

$* *=$ Indicates high significant difference

Table 2: Means \pm SD of some biochemical parameters in male and female Gazella dorcas.

\begin{tabular}{|c|c|c|c|c|c|c|c|c|c|c|c|c|c|c|}
\hline Parameter & $\begin{array}{c}\mathrm{Na} \\
\mathrm{Mg} / \mathrm{dl}\end{array}$ & $\begin{array}{c}\mathrm{K} \\
\mathrm{Mg} / \mathrm{dl}\end{array}$ & $\begin{array}{c}\text { Mg } \\
\text { Mg/dl }\end{array}$ & $\begin{array}{c}\text { IP } \\
\text { Mg/dl }\end{array}$ & $\begin{array}{c}\mathrm{Ca} \\
\mathrm{Mg} / \mathrm{dl}\end{array}$ & $\begin{array}{c}\text { T.P. } \\
\text { Mg/dl }\end{array}$ & $\begin{array}{l}\text { Albumin } \\
\text { Mg/dl }\end{array}$ & $\begin{array}{c}\text { Globulins } \\
\text { Mg/dl }\end{array}$ & $\begin{array}{l}\text { AST } \\
\mu \mathbf{l} / \mathbf{m l}\end{array}$ & $\begin{array}{l}\text { ALT } \\
\mu l / m l\end{array}$ & $\begin{array}{l}\text { Creatinine } \\
\qquad \mathrm{Mg} / \mathrm{dl}\end{array}$ & $\begin{array}{c}\text { Uric acid } \\
\text { Mg/dl }\end{array}$ & $\begin{array}{c}\text { Urea } \\
\text { Mg/dl }\end{array}$ & $\begin{array}{c}\text { Bilirubin } \\
\text { Mg/dl }\end{array}$ \\
\hline \multirow[t]{2}{*}{ Males } & 114.2 & $2.1 \pm$ & $0.9 \pm$ & $5.7 \pm$ & $11.5 \pm$ & $8.7 \pm$ & $3.2 \pm 1.2$ & $5.7 \pm 3.0$ & $79.2 \pm$ & $15.1 \pm$ & $363.4 \pm$ & $0.4 \pm$ & $69.6 \pm$ & $4.3 \pm 5.6$ \\
\hline & \pm 6.6 & 0.5 & 03 & 2.1 & 5.1 & 4.03 & & & 44.7 & 8.1 & 103.4 & 031 & 49.8 & \\
\hline \multirow[t]{2}{*}{ Females } & 115.8 & $2.1 \pm$ & $1.1 \pm$ & $5.6 \pm$ & $13.7 \pm$ & $10.5 \pm$ & $2.6 \pm$ & $7.0 \pm 2.5$ & $102.2 \pm$ & $15.2 \pm$ & $332.6 \pm$ & $0.6 \pm$ & $76.04 \pm$ & $2.8 \pm 2.8$ \\
\hline & \pm 4.8 & 0.3 & 0.7 & 2.0 & 2.7 & 3.11 & 0.89 & & 58.9 & 9.2 & 123.2 & 0.3 & 1.0 & \\
\hline \multirow{2}{*}{$\begin{array}{l}\text { Overall } \\
\text { mean }\end{array}$} & 115.0 & $2.1 \pm$ & $1.0 \pm$ & $5.7 \pm$ & \multirow{2}{*}{$\begin{array}{c}12.6 \pm \\
4.14\end{array}$} & $9.6 \pm$ & $2.9 \pm$ & $6.3 \pm 2.8$ & $90.7 \pm$ & $15.1 \pm$ & $348.0 \pm$ & $0.5 \pm$ & $72.8 \pm$ & \multirow[t]{2}{*}{$3.5 \pm 4.4$} \\
\hline & \pm 5.7 & 0.4 & 0.6 & 2.0 & & 3.6 & 1.2 & & 52.7 & 8.5 & 112.3 & 0.3 & 44.7 & \\
\hline $\begin{array}{c}\text { Level of } \\
\text { significance }\end{array}$ & N.S. & N.S. & N.S. & N.S. & N.S. & N.S. & N.S. & N.S. & N.S. & N.S. & N.S. & N.S. & N.S. & N.S. \\
\hline
\end{tabular}

N.S. = Indicates non-significant difference

$* *=$ Indicates high significant difference

Table 3: Means \pm SD of some haematological values of Gazella dorcas in Sudan.

\begin{tabular}{ccccc}
\hline Parameters & $\begin{array}{c}\text { TRBCs } \\
\left(\mathrm{Cell} / \mathrm{mm}^{6}\right)\end{array}$ & $\begin{array}{c}\text { TWBCs } \\
\left(\mathrm{Cell} / \mathrm{mm}^{3}\right)\end{array}$ & $\begin{array}{c}\text { PCV } \\
(\%)\end{array}$ & $\begin{array}{c}\mathrm{Hb} \\
(\mathrm{gm} / \mathrm{dl})\end{array}$ \\
\hline Males & $9.8 \pm 1.8$ & $3.9 \pm 0.8$ & $45.0 \pm 2.9$ & $15.0 \pm 1.0$ \\
\hline Females & $10.5 \pm 2.6$ & $3.8 \pm 1.5$ & $45.3 \pm 5.5$ & $15.1 \pm 1.8$ \\
\hline Overall mean & $10.1 \pm 1.9$ & $3.9 \pm 1.0$ & $45.1 \pm 3.5$ & $15.0 \pm 1.2$ \\
\hline Level of significance & N.S. & N.S. & N.S. & N.S. \\
\hline
\end{tabular}

N.S. $=$ Indicates non-significant difference 


\section{DISCUSSION}

Haematological and biochemical values are important for assessing the health and nutrition of the animals and it is known that almost all diseases cause some biochemical changes in the body of the affected animal. Therefore, haematological reference values may help in the diagnosis of diseases and disorders affecting human and animal health. Normal physiological data from wild species are often difficult to obtain, because the number of animals usually available for studying these data is generally limited, and frequent and systematic sampling can disrupt the management and well-being of these animals (Hawkey et al., 1984).

The lack of significant variations in the biochemical parameters of examined Dorcas gazelles between summer and winter in this study might be due to the high adaptation ability of this desert species of gazelles to the different seasonal climatic conditions. Dorcas gazelles are known to be highly capable in maintaining their body water balance during winter and summer (Ghobrial, 1967). Some authors observed increased urea level in Dorcas gazelles serum during summer seasons and attributed this to dehydration (Mohammed et al., 1988). However, the higher values of serum urea reported during winter in this study compared to those reported in the summer might be attributed to increased nutritional demand during winter which resulted in gradual increase in serum urea levels than in summer (Ghobrial, 1967 and Sayied et al., 2011). Other values of serum chemistry reported in this study were very close to those reported by Marler (1975) and Faragalla et al. (2005) except for the potassium $(\mathrm{K})$ value which was found to be statistically different in the examined Dorcas gazelles between males and females in the studies of the latter authors.

Although the albumin and creatinine levels, AST activities and uric acid values were higher in the examined gazelles during summer compared to winter, however, the difference was not statistically significant which is in line with the results of Faragalla et al. (2005) in their study on Dorcas gazelles in Sudan.

Regarding the haematological parameters, no significant variations could be observed between the two sexes in the examined gazelles although several authors reported some statistical differences in some haematological parameters (e.g. Faragalla et al., 2005; Reitherk and Detaima, 1994).

In conclusion, in the present study normal hematological and biochemical levels of Gazella dorcas in Sudan were determined. No significant variations were recorded in the levels of most of the parameters investigated. However, the values for urea were higher in the winter compared to the average in summer. These results may be helpful to veterinarians and other scientists who study the diagnosis of gazelle diseases.

\section{ACKNOWLEDGEMENT}

The assistance provided by the staff of the Department of Diagnosis and Pathology and Department of Biochemistry and Nutrition, Soba Laboratory is acknowledged. The help of Mr. Babiker Ahmed Khalifa, at Kuku Veterinary Diagnostic Unit and the contribution of the College students in sample collection and laboratory analysis are appreciated.

\section{REFERENCES}

Abaigar, T. (1993): Haematology and plasma chemistry values for captive Dama gazelles (Gazella dama mhorr) and Cuvier's gazelles (Gazella cuvieri): Age, gender and reproductive status differences. J. Zoo Wildlf. Med., 24: 177-184.

Bush, M.; Smith, E.E. and Custer, R.S. (1981): Haematology and serum chemistry values for captive Dorcas gazelles variation with sex, age and health status. J. Wildlf. Dis., 17:135-143.

Dacie, J.V. and Lewis, S.M. (1992): Practical Haematology. Churchil Livingstone. Edinburgh. UK.

Drevemo, S.; Grootenhnis, J.G. and Karstad, L. (1974): Blood parameters in wild ruminants in Kenya. J. Wldlf. Dis. 1974; 10: 327- 334.

Faragalla, A.M.; Ibrahim, M.T.; Suleiman, O.A.; Mahmoud, Z.N. and Mohamed, O.S. (2005): Some haematological and sero-chemical values for captive Gazella dorcas. J. Sci. Tech. 6(1): $1-4$.

Ghobrial, L.I. (1967): Physiological Adaptation of Desert Mammals. Ph.D. Thesis, University of Khartoum.

Ghobrial, L.I. (1974): Water relation and requirement of the Dorcas gazelle in the Sudan. Mammalia. 38: 88-107.

Ghobrial, L.I. (1970): The water relations of the desert antelope (Gazella dorcas dorcas). Physiol. Zool. 34: 249-256.

Ghobiral, L.I. and Thompson, C.J.L. (1964): Daily cycle of activity of the Dorcas gazelle in the Sudan. J. of Interdisciplinary Cycle.

Gomez, K.A. and Gomez, A.A. (1983): Statistical Procedure for Agricultural Research. $2^{\text {nd }}$. Edition. John Wiley and Sons, New York, USA.

Hawkey, C.M.; Hart, M.G. and Fitzgerald, A.K. (1984): Haematological values in mouflon (Ovis musimon): Influence of age, sex, season and vitamin E status. Res. Vet. Sci. 1984; 36: 37-42. 
Hawkey, C.M.; Frankel, T.; Jones, D.M.; Ashton, D.G.; Nevill, M.G.; Hart, M.G.G.; Alderson, C. and Bircher, P. (1980): Preliminary report of the study of changes in red blood cells of zoo animals during sedation. In: "Comparative Pathology of Zoo Animals". R.J. Montali and G.Migaki (eds.). Simthsonian University Press, Washington, D.C., P. 625-632.

Marler, R.J. (1975): Some haematological and blood chemistry values in two herds of American Bison in Kansas. J. Wildl. Dis., 11:97-100.

Mohammed, S.M.; Ali, B.H. and Hassan, T. (1988): Some effects of water deprivation on Dorcas gazelle (Gazella dorcas) in the Sudan. Comp. Biochem. Physiol. 90:225-228.

Rietherk, F.E. and Detaima, E.C. (1994): Clinical and haematological changes in gazelles during xylazine/katamine anaethesia and following reversal with RX-821002 A., Vet. Rec. 2: 354-355.
Rietman, S. and Frankel, S. (1957): A colorimetric method for determination of serum glutamic oxaloacetic acid and glutamic pyruvic transaminase. American Journal of Clinical Pathology, 28:56.

Seal, U.S. and Schobert, E.E. (1976): Baseline laboratory data for the Grant's gazelle (Gazella granti). J. Zoo Anim. Med., 7: 7-10.

Sayied, A.S.A.; Shigiddi, M.T.A. and Abbas, B. (2011): Serum chemistry of captive Dorcas gazelles (Gazella dorcas, Linnaeus, 1758): Variations with sex, age, season and pregnancy period. Sud. Acad. Sci. J., 4(1): 127-140.

Thompson, J.L.C. and Ghobrial, L. (1965): Water economy of the Dorcas gazelle. Nature, 207: 1313.

Varley, H. (1986): Practical Clinical Biochemistry, $4^{\text {th }}$ edition. William Heinerann Medical Books Ltd., New York.

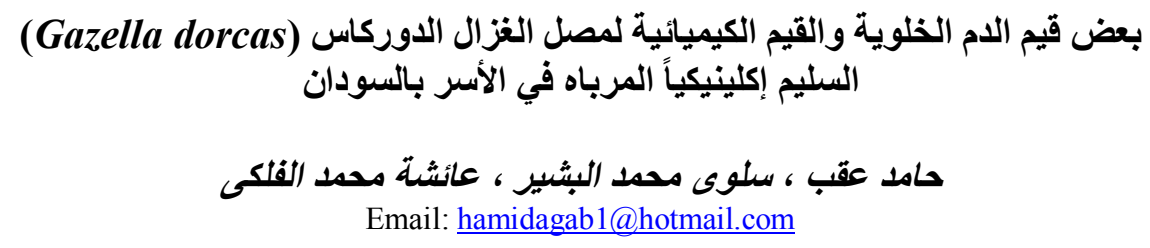

تم قيـاس بعض مكونـات الدم و المكونـات البيوكيميائية في عينـات الدم التي تم جمعها من عدد من غز فز لان الدوركاس (

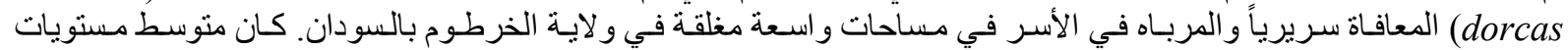

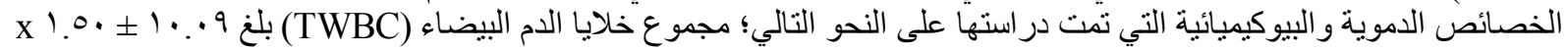

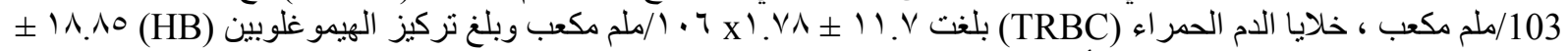

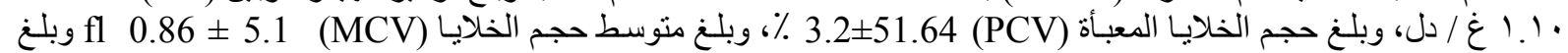

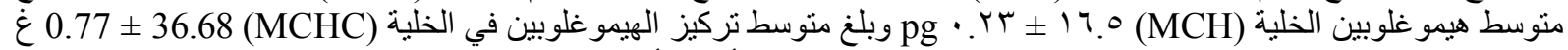

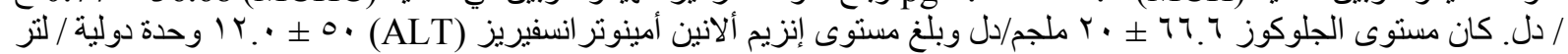

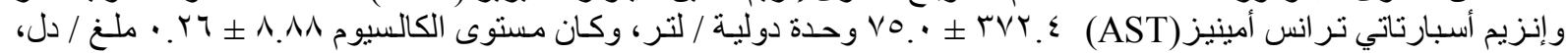

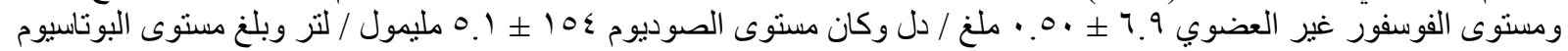

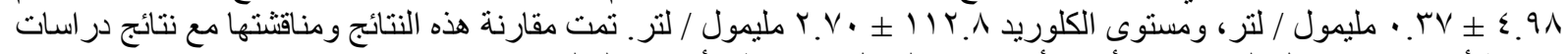

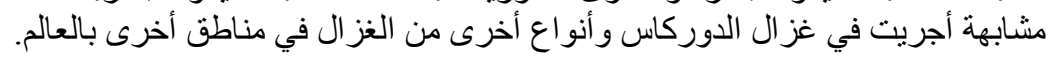
الكلمات الدالة والمفتاحية : در اسة الدم ، القياسات البيوكيميائية، غز ال الدوركاس ، السودان. 